\title{
Institutional Requirements for Building Resilience and Sustainability in Agricultural Land Management in the Central African Sub-region
}

\author{
Ernest L. Molua ${ }^{1,2}$ \& Joan Kagwanja ${ }^{3}$ \\ ${ }^{1}$ University of Buea, Cameroon \\ ${ }^{2}$ Centre for Indepdendent Development Research (CIDR), Cameroon \\ ${ }^{3}$ Land Policy Initiative, United Nations Economic Commission for Africa, Addis Ababa, Ethiopia \\ Correspondence: Ernest L. Molua, Department of Agricultural Economics and Agribusiness, Faculty of \\ Agriculture \& Veterinary Medicine, University of Buea, P.O. Box 63 Buea, Cameroon. Tel: 237-699-494-393. \\ E-mail: emolua@cidrcam.org or emolua@yahoo.com
}

\author{
Received: November 25, 2014 Accepted: June 10, 2015 Online Published: August 28, 2015 \\ doi:10.5539/jms.v5n3p114 URL: http://dx.doi.org/10.5539/jms.v5n3p114
}

\begin{abstract}
Land is critical for economic and socio-cultural development, as well as the core of structural intervention to promote good governance, decentralization and sustainable development. However, Central Africa's current land policies, legislations and administration are remnants of the legacies of the colonial period, which has led to simmering tensions that constrain meaningful development. This paper reviews the centrality of land in promoting better livelihoods, and examines the institutional requirements for building resilience and sustainability in agricultural land management in the Central African sub-region. Comprehensive principles for better agricultural land management in the advent of large-scale land investments are examined. The paper asserts that promoting resilience and sustainability in land management requires that land policy development and implementation is promoted as a package of interlinked measures which includes an effective land administration. The paper concludes that for a win-win outcome, a strategic plan is required for the continued implementation of land policy in a coordinated and timely manner, and efforts made to sequence policy reforms and institutional changes so that they can be adopted and implemented within the existing historical and political context.
\end{abstract}

Keywords: Central African sub-region, agriculture, land institutions, land management

\section{Background}

Land resource is degrading in the Central African sub-region despite its natural capital and ecological wealth (UNEP, 2011). The degradation of its soil, depletion of groundwater, degradation of forest ecosystems, and the depletion of agricultural soil fertility is increasing the need for significant investments in sustainable land management (World Bank, 2013; FAO, 2013). This stress is reinforced by significant population growth of almost 3\% per annum for countries such as Gabon, Democratic Republic of Congo, Republic of Congo, Central African Republic and Cameroon with land natural capital and forest covers which constitute the Congo Basin. Globally, various projections suggest that food production must increase $70-100$ percent by 2050 to meet the demands of a world with 9 billion people and changing diets (Jones, 2003). For, countries within the central African subregion this will require considerable investments in agricultural development - research, institutional support and infrastructural development (Shiva, 2008). Institutional support and infrastructural development are particularly important where agricultural production is closely tied to management of natural resources such as water and soil (Scoones et al., 1996). Raising agricultural growth requires significant investments in managing land resource and ensuring proper functioning institutions on the governance, access and control of land (Barrows \& Roth, 1990). Therefore, for some of the economies in Central Africa that rely heavily on agriculture, land issues are at the heart of their socio-economic development. This is linked to other challenges such as sustainable use of natural forests, and other important emerging issues such as land markets and foreign direct investments, land and climate change, demography and urban development, and the contemporary 'land grab' phenomenon (Cotula et al., 2009; Daniel \& Mittal, 2009) (Note 1). 
Agriculture and forest exploitation contributes almost $40 \%$ the income of countries in the sub-region. Land is therefore sacrosanct to the wellbeing of the economies. De Wit et al. (2009) note that land is not only critical to the economic, social and cultural development, but also a key reason for the struggle for independence for many African countries. However, growing land scarcity has brought land to the fore as part of structural intervention measures to promote good governance, decentralization and sustainable development. This importance was recognized by the Heads of States and Government of the African Union, meeting at the Thirteenth Ordinary Session in Sirte, Libya, from 1 to 3 July 2009, who

urge member states to review their land sectors with a view to developing comprehensive policies which take into account their particular needs; build adequate human, financial, technical capacities to support land policy development and implementation... (AUC, 2009).

This therefore calls for the need to build and enhance the institutional framework that allows land to play a catalytic role in sustainable economic development, which requires amongst others reviewing the database of land information, documenting and disseminating best practices, experience sharing and lesson learning, and tracking land policy development and implementation. This reaffirmation by the African Union member states is recently anchored on the FAO's Voluntary Guidelines on Responsible Governance of Tenure, Fisheries and Forests which espouses that states should strive to ensure responsible governance of tenure because of the centrality of land for the realization of human rights, food security, poverty eradication, sustainable livelihoods, social stability, housing security, rural development, and social and economic growth (FAO, 2012).

In Central Africa, resolving the land question is complex because land has different meanings to different stakeholders: it is a factor of production; it is a family or community property; a capital asset; and a source of cultural identity and/or citizenship. In most of the countries, the constitution declares that the land does not belong to communities and individuals, but it is under the exclusive control of the state. In addition, the State sovereignty over land in Central Africa is not accompanied by the development of appropriate land policy instruments likely to enable sustainable land management (DFID, 1999). Experiences of land policy formulation and implementation are diverse in the sub-region. Overall, however, no significant land reform has been undertaken for a very long time. The land question is still plagued by unequal access and insecure land tenure which is having profound effect on livelihoods.

This paper examines the institutional requirements to building resilience and sustainability in agricultural land management in the Central African sub-region. This is seen as important because access to land and security of tenure are the main means through which food security and sustainable development can be realized because the livelihoods of over $70 \%$ of the population in the sub-region are mainly linked to land and natural resources exploitation. This paper thus develops a framework to promoting resilience and sustainability in land management and exploitation.

\section{Materials and Methods}

This paper is a qualitative scoping review of land management and administration of selected countries in Africa particularly in the Central African sub-region. The assessment relied on information from background documents and reports from various stakeholder workshops involving government officials, non-governmental organizations, civil society including farmers' organizations, private sector representatives, where consensus were reached on elements that could characterize actions and sequential activities needed to develop a land management framework.

\section{Findings on Land Administration and Land Policy in Central African Sub-region}

The main problems bedeviling land administration in the sub-region can be attributed to the abuse of the existing laws and corruption. There are other drawbacks within the land management and land administration structures and practices in the region, such as: (a) the lack of an efficient land information system which documents how much land is occupied by whom and for what purposes and how much land is still left out for further allocation/development. (b) Lack of computerized land information database. With the volume of land information increasing, it is difficult for the existing manual land information management systems to cope. (c) Multiplicity of land administrative procedures compound the problems that land managers and administrators have to deal with. (d) The lack of clearly defined institutional hierarchy for land administration which results in complicated land disputes.

These challenges in land administration could be attributable to the total lack of a national land policy. Land policy is a set of socio-economic, legal, technical and political measures that dictate the manner in which land, and benefits accruing from land are allocated, distributed and utilized. A National Land Policy promotes and 
ensures a secure land tenure system, encourages the optimal use of land resources, and facilitates broad-based social and economic development without upsetting or endangering the ecological balance of the environment. It further ensures that land is made available in sufficient quantities, in appropriate locations and at acceptable costs for different users. The African Union Framework and Guidelines on Land Policy in Africa notes that:

Although land is central, development initiatives in many countries do not always take comprehensive account of this reality. African governments need to take appropriate measures to ensure that land plays its primary role in the development process and particularly in social reconstruction, poverty reduction, enhancing economic opportunities for women, strengthening governance, managing the environment, promoting conflict resolution and driving agricultural modernization (AU-ECA-AfDB 2010a).

This afore quote is a true picture in the Central African sub-region were the current status of land policies, legislations and administration are remnants of the legacies of the colonial period (Kofele-Kale, 2007; Yenshu, 1998). The history of colonialism in the sub-region is varied amongst the states, with indirect French rule having led to the promotion of peasant farming for exports without land expropriation, generating multiple export enclaves, which built differentiating indigenous elite alongside the peasantry. In Cameroon and the Democratic Republic of Congo, plantation economies of the European merchant capitalists coexisted with peasantries in a bimodal agrarian context. This is still true for Cameroon where such large plantations (for the export of banana, rubber and oil palm) with significant land acquisitions are today managed by state-owned corporations and private capitalists thus creating a situation in which surrounding communities are deprived of prime agricultural land (Pemunta \& Fonmboh, 2010; Kofele-Kale, 2007; Konings, 2003; Konings, 1996).

Overall, land scarcity, denial of access to natural resources by the State through laws which exclude many, and privatization of land, have contributed to land administration and decision-making conflicts between the State and local communities and various interest groups. The State's responsibility for the formulation and the implementation of land policy does not only ignore customary land rights, but has also led to dualism, whereby customary rights are overshadowed by government's assertion on land ownership. Mindful of such impediments, the AU-ECA-AfDB consortium (2011) identified some key issues for resolution in the development of an Africa-wide land policy framework, to include: state sovereignty over land, unequal distribution of land resources, dualism (or pluralism) in property systems, land tenure security, good governance in land administration, enhancing productivity issues in agriculture, sustainable management of the environment, protecting the commons, managing pastoral land use, improving land rights security in urban and peri-urban land areas, addressing gender biases in land relations, managing the impact of debilitating diseases such as HIV/AIDS, restructuring land administration systems and institutions, and managing land issues in post-conflict reconstruction. The peculiarity of the Central African sub-region was reechoed in the consultation of stakeholders (AU-ECA-AfDB consortium, 2010b) who prioritized the land problem in Central Africa as follows:

1) Lack of land policies, inappropriateness of the existing texts and the multiplicity of decision making authorities in the area of land tenure;

2) Gender and land, particularly women's access to land and land ownership;

3) Capacity building needs in land tenure issues, especially for land administration staff at the national, regional and local level;

4) Insufficient human and financial resources and lack of appropriate land management tools;

5) The dominance of centralization in land management and lack of participation.

The prevalence of these challenges is because since independence, there are few experiences on land reforms, and existing legislations are old and characterized by the absence of consultation either in elaborating or updating the existing legislations (Byres, 2004). Since most countries do not have a formal coherent land policy, sectoral instruments that target the forest and urban areas have served to regulate access to lands. Relying on such instruments has been less than satisfactory in addressing land matters, and other issues have emerged to crowd-in the land challenge. These include: good governance and peace keeping related to land management; achieving sustainable resource management with special attention to forest resources; and economic growth, poverty alleviation and secure land rights (Sachs, 2005; Andersson, 2007).

Both pre-colonial and post-colonial questions in relation to land have led to simmering tensions which constrains meaningful development. In some countries in the sub-region including Chad, Central African Republic, Cameroon and the Democratic Republic of Congo, there have been violent episodes, and land-related deep rooted tensions amongst communities in other states such as the Republic of Congo with potentials to erupt into 
conflict with disastrous outcomes as a result of contests to accessing land (World Bank, 2007a). Whilst in other countries such as Gabon there have not been landmark events and political events justifying the need to respond to social and economic pressures. However, the recognition of national and international commitments whether on human rights or food security geared towards equality, ensuring that those who are dependent upon land can keep it and use it more productively, and to reap from the economic benefits through marketing opportunities and globalization, these conditions provide comprehensive justification for land policy development or reformulation that addresses the needs and expectations of diverse stakeholders. This not only means periodically visiting the land policy but reformulating land policy to give primacy of place to the land concerns of the poor, both women and men, who are the majority of land users in all countries in the sub-region. In this regard, the AU-ECA-AfDB consortium (2010b) identifies four key challenges to land policy formulation and implementation in Central Africa as: ensuring broad-based participation in further land policy development; reframing land policy through the decentralization process; Implementing a land policy aimed at sustaining agropastoral systems; and developing land policy adapted to dealing with unpredicted events. However, land policy development is a complex and interactive process which can be reduced to some fundamental steps summarized in Box 1.

Box 1. Sequencing land policy development process

1. Stakeholder consultation and identification of salient problems in the land sector

2. Preparation of working drafts for further discussion with stakeholders

3. Appraisal of institutional and financial/budgetary options

4. Refinement, processing and approval of the national land policy

5. Design of implementation programmes and rationalization of institutional responsibilities

for implementation

6. Enactment of new and revision or repeal of existing land and land-related legislation

7. Further dissemination of information to the public, training and capacity building to support implementation

Source: AU-ECA-AfDB (2010a).

Where there exist land policies or proxy-instruments which confer a vision for proper land use, land policy implementation has been slow and disappointing. Land administration has emerged as an important impediment to land policy implementation. The key components of land administration include - juridical, regulatory, fiscal, cadastral and conflict resolution agencies. Major reasons for the failures of these components include: (a) land administration institutions or agencies that draw their mandates from colonial heritage characterized by operational conservatism; (b) slow inefficient institutions that that lack technological know-how to manage contemporary land reform programmes; and (c) complex and inaccessible bureaucracy, implicated in patronage and corruption (AU-ECA-AfDB, 2010c). Land administration systems in the subregion have generally failed to perform the functions for which they were designed; rather it has been incidental in land reforms across countries in the region. Land administration has therefore been acknowledged as a missing link in agrarian development in the subregion.

A land policy which seeks to ensure, perhaps, legally secure access to land for the majority, property taxation measures that would allow for the provision of necessary services, incentives for agriculture investment, innovative and more dynamic approaches to land use planning and development or possibly effective land management and administration institutions should be implemented as shown in Box 2, which highlights systematic identification and execution of all steps necessary for the attainment of the goals and prescription set out in the national land policy. The policy must be translated into a programme designed to deliver a wide range of services and benefits to the community and to sectors which depend on the land system for value addition. Efficient, cost-effective and sustainable delivery of that range of services and benefits require that a number of additional steps be taken as noted in Box 2. More important is the built-in tracking system of land policy formulation and implementation, required to make timely re-adjustment to policy development process, to take 
appropriate measures to ensure the effectiveness and efficiency of land policies, to learn from past successes and failures and to enable governments to manage emerging issues and other incidental developments in the land sector in a systematic way. More important, an effective land administration will require the development of a strategic plan for the continued implementation of the policy in a coordinated and timely manner and prioritize critical areas for which a number of projects and programmes will be prepared.

\section{Box 2. Necessary steps for effective land policy implementation}

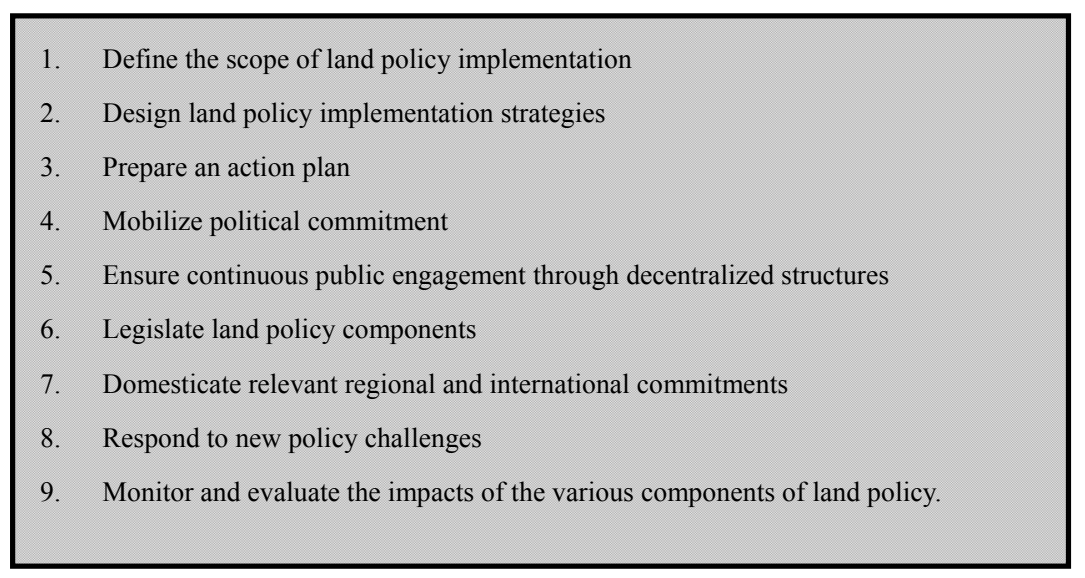

Source: AU-ECA-AfDB (2010c).

The failure to agree on land policy implementation strategies, or where there are defects in policy development, perhaps due to lack of baseline data and inadequate financial and institutional resources; these have combined with poor land administration to deprive communities at the forefront of agricultural exploitation from securing rights to access land, exercising their rights to land and protecting their land rights. In some communities, addressing these rights means correcting for past injustices. Unable to address past injustices and current challenges means sowing seeds of failure in the future to promote comprehensive agrarian development. Increased and more secured access to land and natural resources for poor people is a key means for achieving food security (Berry, 1984; Rosegrant et al., 2001). This is compromised where land administration fails and government economic plans do not seriously link land issues with land productivity concerns. As a consequence poverty is seen to be driven by inadequate land access, inability to use land effectively, poor quality land, and environmental degradation (Griffin et al., 2002).

In fact, most national economic plans are weaker on the specifics of how land policy will be used to reverse poverty and promote economic development (Sachs, 2005). In Cameroon's development vision document Growth and Employment Strategy for 2035, and Gabon's Vision 2035 (Gabon Emergent), secure tenure and access to land and other productive assets have not been identified as critical incentives for investments in the agricultural sector. Other countries developing such plans, whether Chad or Republic of Congo, must give adequate attention on land access and management in shaping agricultural sector development. Improving access to land and management practices that ensure sustained increases in agricultural productivity sustains the resource base that provides the foundation for food production (Migot-Adholla et al., 1991; Berry, 1984).

Where existing policies, laws and regulations are not yielding the expected results, there is need to reform particularly where history has resulted in adverse legacies, where existing rights systems and the institutions that manage them are weak or corrupt, and where recent policies have created inefficient and unsustainable pricing, subsidies, and other privileges, massive reforms in land and water rights, policies and institutions are needed (de Janvry et al., 2001; Deininger, 2003). New demands for land and water from urban populations and from the environment add to the urgency of reforms (Gilland, 2002; Jones, 2003). Both the rewards and the difficulties of such reforms are therefore enormous. Reforms may require great effort but yield little impact, or even backfire, increasing insecurity and conflict over access. Reform efforts should begin with the recognition that there is no one-size-fits-all solution to policies, rights and institutions, and there is no ideal solution that can be applied every-where. Reforms should be adapted to the specific situation existing in a country or region. The World Bank (2007b) notes that careful assessment is required of the existing situation with respect to the: 
i. role of land and water in the national development framework;

ii. constitutional and legal status of these resources;

iii. systems of rights and the distribution of such rights;

iv. systems for the administrations of rights and transfers of land and water;

v. land- and water-use management; and

vi. implementation of regional and international land and water policy commitments.

The experiences of other countries show that reform is a long-haul process (Hernandez, 2010; Gordillo, 2010; Tamrat, 2010). Many years of discussions and debate usually precede the formulation of land and water policies and the drafting and passing of legislation (Endo, 2010). Reforms are often opposed by existing right holders if they do not recognize their pre-existing rights. Beneficiaries of distortions, subsidies, and other privileges, will also staunchly defend them. It is therefore important to choose. The objectives and sequencing of reforms, as well as their specific policy, rights and institutional changes so that they can be adopted within the existing historical and political context and implemented. Important process elements for reforms would include:

- Sequencing of reform allowing for public consultations and consensus-building processes that are informed by technical knowledge and judgment.

- Actively involving those affected or legitimate representatives in the decision-making process regarding land and water (re)allocation processes as well as investments.

- $\quad$ Providing different options for the definition of such rights and the corresponding administration systems to accommodate different situations encountered in the same country.

- $\quad$ Consideration of the feasibility of direct command and control versus indirect incentives approaches.

- Appropriate land and water management information systems, conflict resolution mechanisms and management systems.

- $\quad$ Political will generated by dialogue and debate, and by organization of the groups that stand to gain from the reforms to:

○ push through the policies, legal reforms and issue the associated regulations;

○ provide for the necessary financial allocations for the institutions in charge of implementation, and for their institutional capacity development;

○ implement the allocation, registration, and updating of the rights that are being created, redistributed or formalized; and enforce the rights created, formalized or reallocated transparently and equitably.

- Continued development of the capacity of the state, communities and user associations to allocate and administer rights systems to avoid and manage conflict, including the information systems and technologies needed to do so.

\section{Discussion on Promoting Resilience and Sustainability with Large-Scale Land Investments}

Neo-liberal economic policy recommendations of deregulation, liberalization, privatization and commoditization by the World Bank, the IMF and the World Trade Organization implemented by developing countries such as those in the sub-region have increased the risk, vulnerability and fragility of agriculture. While this has provided limited opportunities, it has also led to large multinational organizations having more access to developing country markets and resources especially land. Thus, recent large-scale acquisitions of cheap farmland and fairly easy access to land in Central Africa, by governments and speculators concerned about stability of food supplies is creating opportunities, challenges and risks has been unprecedented (Cotula et al., 2008; Cotula et al., 2008; Braun \& Meinzen-Dick, 2009; Deininger, 2011), with the costs outweighing the benefits for local people losing access to the resources on which they depend for their livelihoods (Cotula et al., 2008; Daniel \& Mittal, 2009; Sulle \& Nelson, 2009; Deininger, 2011).

The sub-region's growing population of about 3\% per annum since independence, with over $70 \%$ of the population drawing their subsistence from land, investments in agricultural land by foreign investors have thus heightened vulnerabilities with local communities marginalized having to make way for agribusiness projects. The privatization of land and focus on large scale projects e.g. industrial farming have pushed farming communities off their land into marginal unfertile lands, increasing rather than alleviating poverty. Productive fertile farmland is a sine qua non for land to fulfill its socio-economic importance in the development of Central 
Africa. Productive agricultural land is unquestionably important for the realization of agrarian growth and poverty reduction (Griffin et al., 2002).

How sustainable are agricultural land-based institutions? There are diverse definitions of sustainability all being offshoots of the Brundtland (1987) report. In the current assessment, this paper views sustainability with respect to land based institutions as: 'ensuring that the functionality of institutions required to support land acquisition and its management are maintained with long-term benefits for land-users and stakeholders.' Several factors which may contribute to this long-term impact would include:

$\checkmark$ political sustainability - government commitment, an enabling policy environment, stakeholder interests, lobby groups and political influence/pressure;

$\checkmark$ social sustainability - social support and acceptability, community commitment, social cohesion;

$\checkmark$ ownership - whether or not communities, local government and households accept and have a positive perception on agricultural institutions;

$\checkmark$ institutional sustainability - institutional support, policy implementation, staffing, recurrent budgets;

$\checkmark$ economic and financial sustainability - resilience to economic shocks, financial viability, reduced household vulnerability and increased capacity to cope with risk/shocks;

$\checkmark$ technical sustainability - technical soundness, appropriate solutions, access to land management technologies;

$\checkmark$ environmental sustainability - land-uses' positive/negative contributions to soil and water preservation and management, resilience to external environmental shocks.

At the farm-level, the sustainability of agricultural land-use and institutions would have to be assessed in terms of viable production systems, cultural expediency and the satisfaction of basic social and economic needs. Meanwhile, at the national or sub-regional level emphasis must be on the population's adaptability to a changing natural environment, factors contributing to social equity, and the coherence of national land policy frameworks. Sustainability must ensure both farm-level and household/community-level resilience. The ability of society to manage resilience depends somewhat on the institutions, capacities for self-organization, adaptation and learning. This will mean not only promoting interventions which increase household income and assets, but also creating and promoting situations in which households and communities are able to handle dynamic and unexpected changes without negative repercussions, are able to recover loss of land, and capable of building positively on the lessons learned and experiences of these hardships. This further implies that communities in the Central African sub-region should be able to expect increased internal and external pressure on their land resources and adapt to these consequences or change through clear decision-making processes, collaboration, and management of resources internal and external to the community. This is congruent with the development plans and economic vision of most countries in the region to strengthen the sustainability of public funded large-scale development projects with respect to alleviating rural poverty and retain the benefits of such projects over time.

Despite this developmental vision, specific challenges remain, which include:

a. Strengthening land tenure rights and reducing land conflicts without excluding small farmers from new economic opportunities.

b. Designing inclusive, sustainable business models and partnership arrangements for small farmer participation in agribusiness and value chain development.

c. Appropriate institutional frameworks to improve coordination and delivery of effective rural advisory, information and financial services to achieve sustainable agricultural intensification and better market access.

d. Strengthening governance and delivery arrangements for rural development processes to ensure positive impacts of agricultural investment on local economies.

In sum, therefore, in order to ensure sustainability in land acquisition, land managers must consider four essential dimensions:

1) Institutional sustainability - functional institutions will be self-sustaining after the project ends.

2) Household and community resilience - resilient households and communities take intentional action to enhance the personal and collective capacity of their members and institutions to respond to and influence the course of change. 
3) Environmental sustainability - an environmentally sustainable system must maintain a stable resource base, avoid overexploitation of renewable resources and preserve biodiversity.

4) Structural change - the structural dimensions of poverty are addressed through the empowerment of poor and marginalized rural households.

These dimensions, when properly adhered to, would guarantee economic incentives for land investment such as prices, land rents and taxes, and ownership/rights (Basu, 1996; Diallo \& Mushinzimana, 2009; Arezki et al., 2010). These incentive measures, when implemented appropriately, can affect the decision-making process and motivate land owners and users to protect land, conserve its biodiversity and exploit it efficiently for agricultural and non-agricultural uses. Economic incentives play out differently under differing enabling institutions. Other institutions that influence economic incentives include the rule of law and good governance, the relative focus on public systems versus private development, the role of decentralization in the form of issuance of land certificates, and the existence or absence of well functioning farmers associations (de Janvry et al., 2001). The most important among these institutions have been noted to be property rights for farmers and rural land exploiters (Deininger, 2003; Fitzpatrick, 2005).

Positive economic value of land provides additional incentives for exploitation, the securing and exercising of rights. It is therefore proper that land policies though independent from other proximate sectors, yet should be considered within the totality of agricultural policy. Box 3 highlights the criteria for sustainability rating in agricultural land management. Agricultural policies and programmes that may contribute to sustainable land management may include a number of specific measures including broadening access to agricultural inputs, improved research and extension service, introduction of smallholder friendly technologies, soil conservation, improving access to domestic and international markets, irrigation, developing producer cooperatives and associations, and promoting family planning to reduce land use pressure, and land redistribution targeting access women (Cousins \& Scoones, 2010; Scoones et al., 1996).

Box 3. Criteria for sustainability rating in Agricultural Land Management

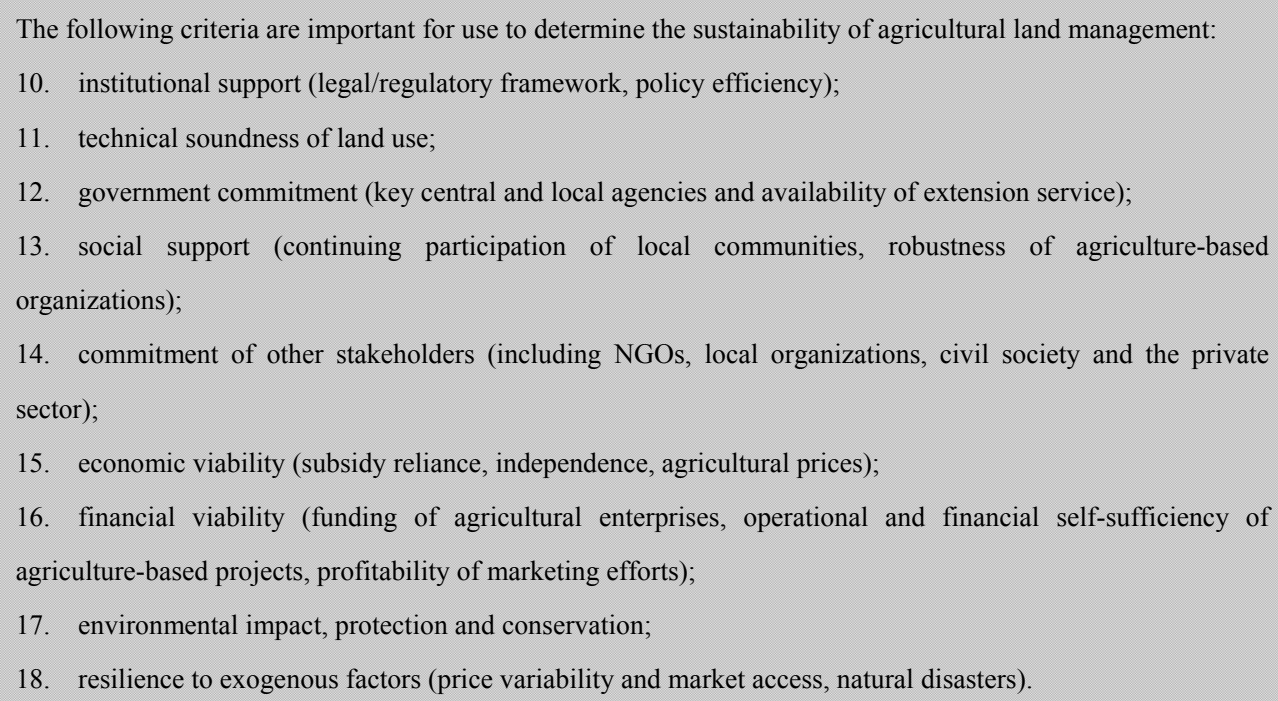

In the case of agricultural land use, comprehensive principles and impact indicators for the implementation of equitable acquisition and better farmland management include:

- Principle 1: Good governance and respecting of indigenous rights. Most large-scale agricultural investments are in sparsely populated areas, for which indigenous ethnic groups lay claim. These groups must be consulted, and the agreements from consultations are noted and enforced. Good relationships and understanding with the local population are essential to guarantee a successful long term agricultural business with desirable social impacts.

- $\quad$ Principle 2: Respecting existing land and resource rights. This deals with the use and ownership of land and other natural resources on acquired or managed parcels. This is a paramount in the Congo Basin where land 
ownership is often not or poorly regulated. In the case of land-based agriculture foreign direct investments, when purchasing land, the investors must comply as a minimum with local laws and regulations.

- Principle 3: Promoting environmental sustainability. This is about the protection of the environment and sustainable management of crops, land and the farm environment, for example by combating erosion and protecting biodiversity. This requires a survey of environmental risks, which is carried out by all external managers. The environmental risks differ widely depending on the region. For the Congo Basin countries, the emphasis should be on arresting deforestation, soil degradation and increasing production capacity in a sustainable manner (for example by investing in improved soil quality).

- Principle 4: Upholding high business and ethical standards. The fourth principle concerns compliance with local laws and regulations, including in countries where compliance is not always strictly enforced. This requires investors to apply high ethical business standards. According to Deininger et al (2011), investors must ensure that 'projects respect the rule of law, reflect industry best practice, are economically viable, and result in durable shared value.'

- Principle 5: Reporting on activities and progress towards implementing and promoting the Principles. Frontline ministries dealing with land and biodiversity and ecosystem services will have to report periodic progress made in implementing these key land management Principles. And when these institutions assess new agricultural investments, these Principles must form part of the selection process.

In sum, therefore, promoting resilience and sustainability in land management requires that land policy development and implementation is promoted as a package of interlinked measures, with land administration as the crux for effective policy outcomes. The framework in figure 1 shows that the comprehensive policy vision has to be translated into a legal package that should facilitate the implementation, depending on the legal system of the country. The legality acquired through state involvement (i.e., approvals through formal institutions that administer land access) confers legitimacy in exercising and defending land rights. The land policy, administrative and legal framework would have to be consistent with other national and international obligations or commitments such as the Right-to-Food and the Millennium Development Goals which Central African states are signatories.

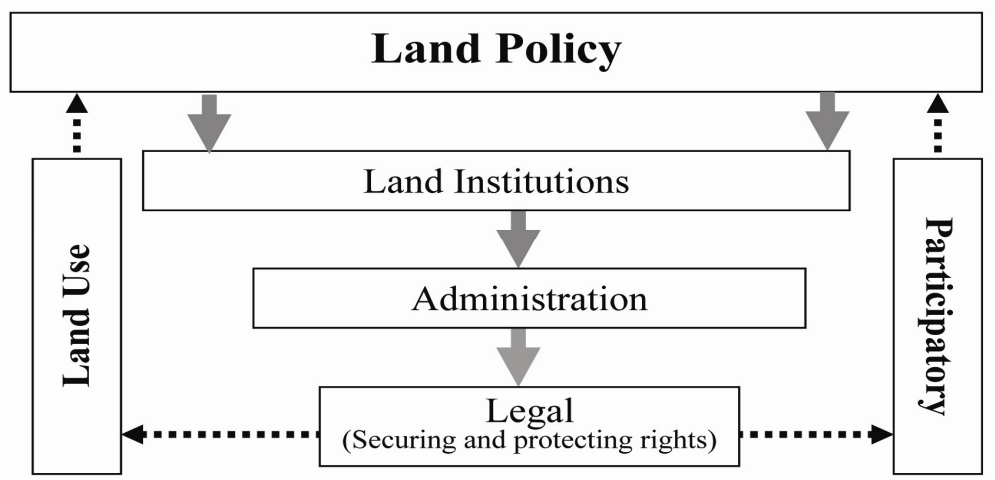

Figure 1. Promoting resilience and sustainability in land use management

Source: authors' conceptualization.

For comprehensive sustainable development, the legal recognition should thus ensure customary rights are recognized and visible with customarily acquired rights given legal protection (see Fitzpatrick, 2005). Therefore, the structure and content of the policy and laws should ensure the access, use and hold of land. Adequately incorporating the expectations of land users requires that the land policy formulation process is consultative and participatory with the effective involvement of all non-state actors, particularly civil society, farmers' organisations, traditional authorities, women's groups and the private sector. Consultation and participation has been acknowledged to contribute to responsible governance of tenure of land, fisheries and forests (FAO, 2012). This will not only promote the use of land but also provide incentives for investment, promote ecological stewardship and address socio-cultural sensitivities in the use of land thus resulting in increased production and economic wellbeing. 


\section{Conclusion}

This importance of land means that governments in the region will have to develop policies in a manner that is inclusive and responsive to the needs of all land users, contribute to political stability, promote gender equity, foster the reduction of conflict, enhance the sustainable management of natural resources, ensure orderly urban development, and efforts which put all stakeholders on the path to higher economic growth and a better quality of life. The successful implementation of land policies, i.e. executing measures identified by the state to promote the principles adopted in the basic texts governing land tenure for countries in the sub-region, shall therefore depend on the effectiveness of measures taken to apply land policies, bringing land management institutions closer to the people and ensuring that different groups of actors participate effectively in land management and secure tenure measures. In this regard, land tenure policies that equitably provide legal, long-term, sustained tenure security would have to ensure the devolution of power to local entities to negotiate and institute new rules of access and use of resources, recognition of customary rights through demarcation of territorially controlled lands, promote systematic registration of valuable lands and resources where records do not currently exist, ensure clarification of the status of occupants of state lands and create transparent conflict resolution mechanisms. The heart of the land tenure policy should therefore be to maintain flexibility in customary and statutory tenure systems, but also, on a case-by-case basis, to foster rapid adjustment of property rights regimes to new environmental and social conditions. Bringing this to fruition will require that states in the region regularly budget for land initiatives such as building databases, facilitating access to information on land policies and laws, consultative bodies and land observatories at national and district levels, building capacities of personnel for the implementation of land projects and programmes, and where necessary the revision and reformulation of land policies and governing institutions.

\section{Acknowledgements}

The authors are grateful to the staff of the Land Policy Initiative (LPI) of the United Nations Economic Commission for Africa (UNECA) for insightful comments and data collation, and also to the reviewers for helpful comments on earlier versions of this paper. The views expressed in this research are those of the authors and do not necessarily reflect the views or policies of UNECA, or any other organization where the authors work.

\section{References}

Andersson, J. A. (2007). How much did property rights matter? Understanding food insecurity in Zimbabwe: a critique of Richardson. African Affairs, 106(425), 681-690. http://dx.doi.org/10.1093/afraf/adm064

Arezki, R., Deininger, K., \& Selod, H. (2010). Interest in Large-Scale Land Acquisition for Agribusiness Investment: Extent and Determinants and the 'Global Land Grab'. Policy Research Working Paper, World Bank, Washington, DC.

AUC. (2009). Declaration of by Heads of States and Government of the African Union, $13^{\text {th }}$ Ordinary Session, Sirte, Libya, 1-3 July 2009. Addis Ababa: African Union Commission.

AU-ECA-AfDB. (2010a). Framework and Guidelines on Land Policy in Africa - Land Policy in Africa: A Framework to Strengthen Land Rights, Enhance Productivity and Secure Livelihoods. Addis Ababa: AU-ECA-AfDB Consortium (African Union, UN Economic Commission for Africa, African Development Bank).

AU-ECA-AfDB. (2010b). Regional Assessment Studies on Land Policy in Central, Eastern, North, Southern and West Africa: Synthesis Report. Addis Ababa: AU-ECA-AfDB Consortium (African Union, UN Economic Commission for Africa, African Development Bank).

AU-ECA-AfDB. (2010c). Consultative Workshops on Land Policy in Africa: Key Messages and Recommendations. Addis Ababa: AU-ECA-AfDB Consortium (African Union, UN Economic Commission for Africa, African Development Bank).

AU-ECA-AfDB. (2011). Land Policy in Africa: West Africa Regional Assessment. Addis Ababa: AU-ECA-AfDB Consortium (African Union, UN Economic Commission for Africa, African Development Bank).

Barrows, R., \& Roth, M. (1990). Land Tenure and Investment in African Agriculture: Theory and Evidence, Journal of Modern African Studies, 28(2), 265-297. http://dx.doi.org/10.1017/S0022278X00054458

Basu, K. (1996.) The Market for Land: An Analysis of Interim Transactions. Journal of Development Economics, 20(1), 163-177. http://dx.doi.org/10.1016/0304-3878(86)90011-8 
Berry, S. (1984). The Food Crisis and Agrarian Change in Africa: A Review Essay. African Studies Review, 27(2), 59-112. http://dx.doi.org/10.2307/524116

Brundtland, G. H. (1987). Our common future: Report of the World Commission on Environment and Development. Oxford, UK: Oxford University Press.

Bush, R. (2010). Food Riots: Poverty, Power and Protest. Journal of Agrarian Change, 10(1), 119-129. http://dx.doi.org/10.1111/j.1471-0366.2009.00253.x

Byres, T. J. (Ed.). (2004). Redistributive Land Reform Today. Journal of Agrarian Change, 4(1-2).

Cotula, L., Dyer, N., \& Vermeulen, S. (2008). Fuelling Exclusion? The Biofuels Boom and Poor People's Access to Land, Rome/London, FAO/IIED.

Cotula, L., Vermeulen, S., Leonard, R., \& Keeley, J. (2009). Land Grab or Development Opportunity? Agricultural Investment and International Land Deals In Africa, IIED/FAO/IFAD, London/Rome.

Cousins, B., \& Scoones, I. (2010). Contested paradigms of 'viability' in redistributive land reform: perspectives from southern Africa. Journal of Peasant Studies, 37(1), 31-66. http://dx.doi.org/10.1080/03066150903498739

Daniel, S., \& Mittal, A. (2009). The Great Land Grab-Rush for World's Farmland Threatens Food Security for the Poor. Oakland, CA, USA, The Oakland Institute.

de Janvry, A., Platteau, J. F., Gordillo, G., \& Sadoulet, E. (2001). Access to land and land policy reforms. In A. De Janvry, J. F. Platteau, G. Gordillo, \& E. Sadoulet (Eds.), Access to Land, Rural Poverty, and Public Action. Oxford: Oxford University Press. http://dx.doi.org/10.1093/acprof:oso/9780199242177.003.0001

De Wit, P., Tanner, C., \& Norfolk, S. (2009). Land Policy Development in an African Context: Lessons Learned from Selected Experiences. Land Tenure Working Paper 14, Land Tenure Management Unit. Rome: FAO.

Deininger, K. (2003). Land Policies for Growth and Poverty Reduction. Washington DC, World Bank.

Deininger, K. (2011). Challenges posed by the new wave of farmland investment. Journal of Peasant Studies 38(2), 217-247. http://dx.doi.org/10.1080/03066150.2011.559007

DFID. (1999). Land Rights and Sustainable Development in Sub-Sahara Africa: Lessons and Ways Forward in Land Tenure Policy. In: African Nations 16-19 February 1999, UK. Department for International Development, London.

Diallo, A., \& Mushinzimana, G. (2009). Foreign Direct Investment (FDI) in Land in Mali. German Society for Technical Cooperation (GTZ) on behalf of the German Federal Ministry for Economic Cooperation and Development, Eschborn, Germany.

Endo, V. (2010). Applying the Land Governance Framework to Peru: Substantive Insights and Local Follow Up. Paper presented at the Annual Bank Conference on Land Policy and Administration, World Bank, Washington, DC, April 26-27.

FAO, UCL. (2013). Analysis of Drivers of Deforestation and Forest Degradation in DRC. Rome: UN Food and Agricultural Organization.

FAO. (2012). Voluntary Guidelines on Responsible Governance of Tenure, Fisheries and Forests in the Context of National Food Security. Rome: UN Food and Agricultural Organization.

Fitzpatrick, D. (2005). Best Practice' Options for the Legal Recognition of Customary Tenure. Development and Change, 36(3), 449-475. http://dx.doi.org/10.1111/j.0012-155X.2005.00419.x

Gilland, B. (2002). World Population and Food Supply: Can Food Production Keep Pace with Population Growth in the Next Half-century? Food Policy, 27(1), 47-63. http://dx.doi.org/10.1016/S0306-9192(02)00002-7

Gordillo, G. (2010). Analyis of the Policy, Legal, and Institutional Framework for Land Acquisition in Mexico. Report produced under World Bank contract, Mexico, D.F.

Griffin, K., Khan, A., \& Ickowitz, A. (2002). Poverty and the Distribution of Land. Journal of Agrarian Change, 2(3), 279-330. http://dx.doi.org/10.1111/1471-0366.00036

Hernandez, M. (2010). Establishing a Framework for Transferring Public Land: Peru'sbExperience. Paper presented at the Annual Bank Conference on Land Policy andbAdministration, World Bank, Washington, DC, April 26-27. 
Jones, A. (2003). Eating Oil: Food Supply in a Changing Climate. Resurgence, 216, 39-45.

Kofele-Kale, N. (2007). Asserting Permanent Sovereignty over Ancestral Lands: The Bakweri Land Litigation against Cameroon. Annual Survey of International \& Comparative Law, 13(1), 103-156. Retrieved from http://digitalcommons.law.ggu.edu/annlsurvey/vol13/iss1/6

Konings, P. (1996). Privatisation of agro-industrial parastatals and Anglophone opposition in Cameroon. Journal of Commonwealth and Comparative Politics, 34(3), 199-217.

Konings, P. (2003). Privatisation and ethno-regional protest in Cameroon. Afrika Spectrum, 38(1), 5-26.

Migot-Adholla, S. E., Hazel, P., Beroit, B., \& Place, F. (1991). Indigenous Land Rights Systems in sub-Saharan Africa: A Constraint on Productivity. World Bank Economic Review, S(1), 155-173.

Pasquini, M. W., \& Alexander, M. J. (2005). Soil fertility management strategies on the Jos Plateau: The need for integrating 'empirical' and 'scientific' knowledge in agricultural development. The Geographical Journal, 171, 112-124. http://dx.doi.org/10.1111/j.1475-4959.2005.00154.x

Pemunta, N. V., \& Fonmboh, N. M. (2010). Experiencing Neoliberalism from Below: The Bakweri Confrontation of the State of Cameroon over the Privatisation of the Cameroon Development Corporation. Journal of Human Security, 6(1), 38-54. http://dx.doi.org/10.3316/JHS0601038.

Rosegrant, M. W., Paisner, M. S., Meijer, S., \& Witcover, J. (2001). Global food projections to 2020: Emerging trends and alternative futures (p. 206). International Food Policy Research Institute (IFPRI) Washington DC.

Sachs, J. D. (2005). The End of Poverty: Economic Possibilities for Our Time. New York: Penguin.

Scoones, I., Reij, C., \& Toulmin, C. (1996). Sustaining the Soil: Indigenous Soil and Water Conservation in Africa. London: IIED Issue Paper 57.

Shiva, V. (2008). Soil Not Oil: Climate Change, Peak Oil and Food Insecurity. London: Zed Books.

Sulle, E., \& Nelson, F. (2009). Biofuels, Land Access, and Rural Livelihoods in Tanzania. London: International Institute for Environment and Development.

Tamrat, I. (2010). Governance of Large-Scale Agricultural Investments in Africa: The Case of Ethiopia. Paper presented at the Annual Bank Conference on Land Policy and Administration, Washington, DC, April $26-27$.

UNEP. (2011). The Democratic Republic of the Congo Post-Conflict Environmental Assessment. United Nations Environmental Programme, Nairobi.

von Braun, J., \& Meinzen-Dick, R. (2009). Land Grabbing' by Foreign Investors in Developing Countries: Risks and Opportunities. Policy Brief 13, International Food Policy Research Institute, Washington, DC.

World Bank. (2007a). Forests in Post-Conflict Recovery in the Democratic Republic of Congo: Analysis of a Priority Agenda. World Bank, Washington, DC.

World Bank. (2007b). Towards Better Land Governance: Conceptual Basis and Pilot Applications of the Land Governance Assessment Framework. Agriculture and Rural Development Department, World Bank, Washington, DC.

World Bank. (2013). Deforestation Trends in the Congo Basin: Reconciling Economic Growth and Forest Protection. World Bank, Washington, DC.

Yenshu, V.E. (1998). The discourse and politics of indigenous/minority peoples rights in some metropolitan areas of Cameroon, Journal of Applied Social Sciences, 1(1), 59-76.

Note

Note 1. Other challenges to comprehensive agricultural development include limited access to agriculture-related technical assistance and lack of knowledge about profitable soil fertility management practices leading to expansion into less-favorable lands (Pasquini \& Alexander, 2005).

\section{Copyrights}

Copyright for this article is retained by the author(s), with first publication rights granted to the journal.

This is an open-access article distributed under the terms and conditions of the Creative Commons Attribution license (http://creativecommons.org/licenses/by/3.0/). 